\title{
SALT DISSOLUTION SINKHOLE AT THE WEEKS ISLAND, LOUISIANA, STRATEGIC PETROLEUM RESERVE STORAGE SITE
}

James T. Neal, Sandia National Laboratories, Albuquerque, NM 87185-0706 and

Robert E. Myers, U. S. Department of Energy, 900 E. Commerce Rd., New Orleans, LA 70123

\section{$\operatorname{Conf}-9504100--1$}

This work was suponited by the United

States Department of Energy under

Contract DE-ACO4-94AL85000.

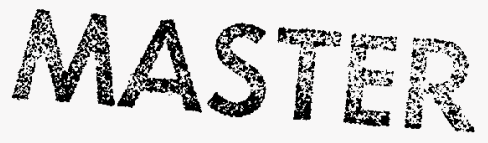

\begin{abstract}
A sinkhole was first observed in May 1992 over the outer edge of the two-tiered former salt mine that was converted for oil storage by the U. S. Strategic Petroleum Reserve (SPR). Results of diagnostic studies which included geophysical, geochemical, drilling, and hydrological methods suggest a direct connection exists between the surface collapse area and the underground mine. The connection was confirmed by correlative measurements of sediment slump rates, piezometric surface deflection, and brine influx rates into the mine. The dissolution of salt below the sinkhole that initiated the leak into the mine was likely caused by several confluent geologic processes, and exacerbated by mining-induced stresses that created fractures which served as hydrologic flowpaths.

Modeling studies of mine stresses show that years of tensional stresses may be required before cracking begins to occur, but once begun can continue to develop, and relieve the stress in that specific regime. The crack regime creates the avenue for incursion of groundwater, very slowly initially, but gradually enlarging as undersaturated groundwater dissolves salt on the sides of the crack.

Mitigative measures include increasing the mine pressurization, slowing the dissolution by injecting brine into the sinkhole throat, and permeation grouting in hydrologic flowpaths.
\end{abstract}

\section{INTRODUCTION}

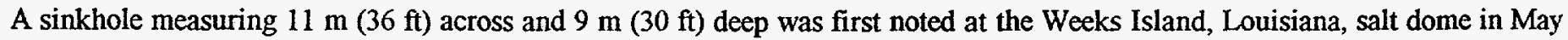
1992, but appeared to be about a year old, based on initial surface appearance and later reverse extrapolation of growth rates. Its position directly over the outer edge of the SPR oil storage chamber, a former room-and-pillar salt mine, caused immediate concern. The association of sinkholes over mines is well established and this occurrence suggested that groundwater influx was probably causing salt dissolution at depth, with associated collapse at the surface. Leaks of groundwater into other salt mines in Louisiana have sometimes led to flooding and eventual abandonment. Consequently, much attention has been and continues to be given to characterizing this occurrence, and to possible mitigative actions. This paper summarizes current knowledge, and describes the diagnostic and risk mitigation program being conducted by the U. S. Department of Energy, operator of the Strategic Petroleum Reserve (SNL / DM, 1994).

\section{LOCATION, OCCURRENCE, AND CHARACTERISTICS}

The Weeks Island salt dome is located $23 \mathrm{~km}$ (14 mi) south of New Iberia, Louisiana, and is the central dome in the Five Islands chain, along with Belle Isle, and Cote Blanche, Avery, and Jefferson Islands. All five have been mined because of their near-surface salt, and their logistical advantage near the Gulf of Mexico and the Intracoastal Waterway. Belle Isle and Jefferson Island are now closed to mining because of deliberate and inadvertent flooding, respectively.

The Weeks Island sinkhole occurs over the southern perimeter of the Upper Level of the two-tiered SPR mine (Figures 1, 2), which has held 73 million barrels of crude oil since 1981. The mine was originally opened in 1902 and salt was extracted commercially until 1977, at which time Morton Salt developed a new mine immediately adjacent to the northwest while the older workings were converted for oil storage. Minor leaks of water had been noted at various times during the 75 years of active mining, but inmine grouting was able to control inflow.

The nearly vertical sidewalls in the surface sediments surrounding the sinkhole caused some puzzlement initially, but were readily explained geologically as typical of Pleistocene loess deposits which cap the island. The sinkhole was also directly beneath a former residence of the now dismantled Morton townsite, which appears to have no relationship to the sinkhole origin. 


\section{DISCLAIMER}

Portions of this document may be illegible in electronic image products. Images are produced from the best available original document. 


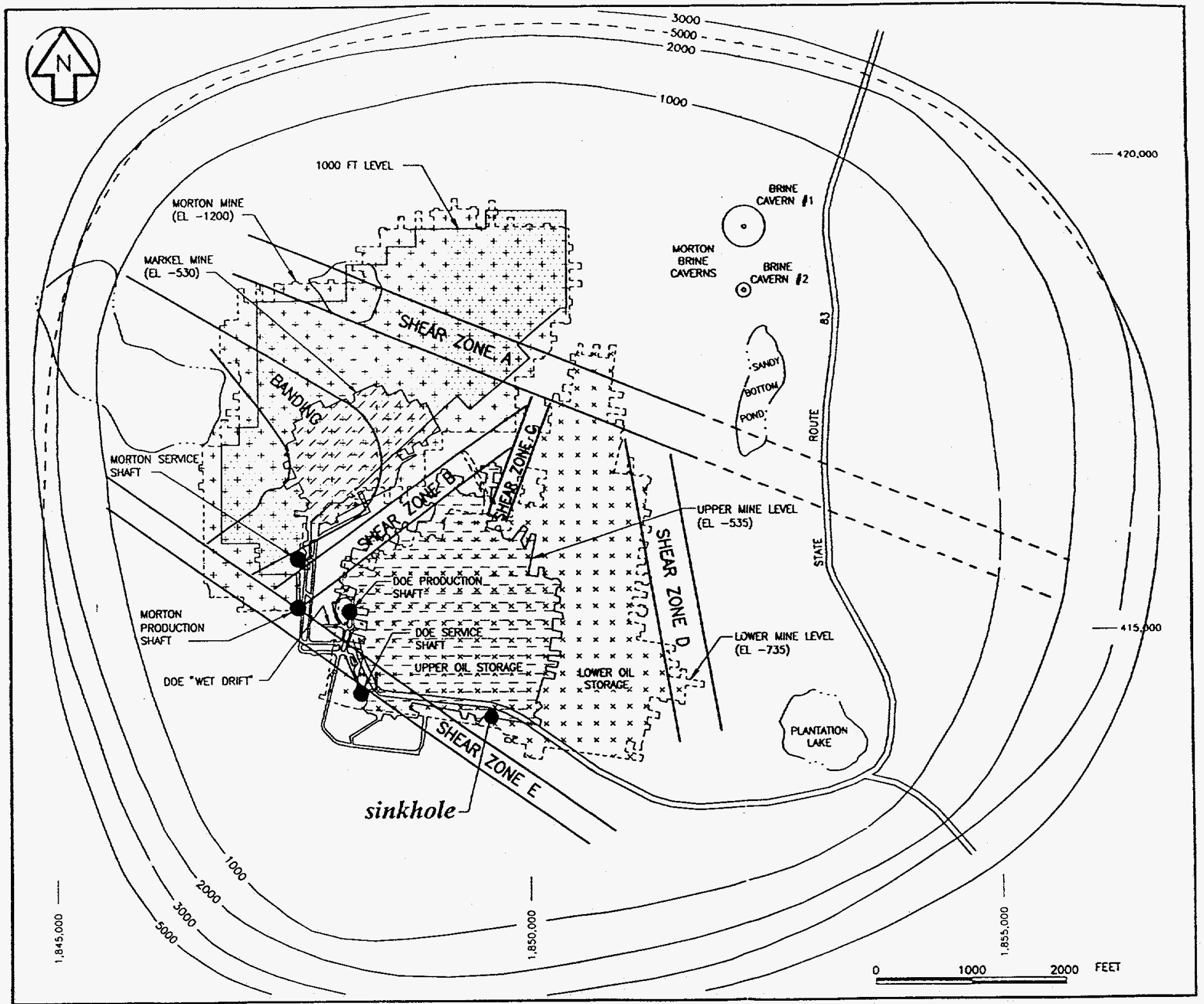

Figure 1 Weeks Island salt dome, Louisiana, showing location of the sinkhole, shear (anomalous) zones, mined areas, and contours atop the salt stock (below sea level).

The sediment cover, consisting of alluvial deltaic deposits of the ancestral Mississippi River, is about $56 \mathrm{~m}$ (185 $\mathrm{ft}$ ) thick over the top of salt, which lies some $30 \mathrm{~m}(98 \mathrm{ft})$ below sea level at the sinkhole. The water table conforms generally with sea level over the dome, but fluctuates with topography and frequent torrential rains.

- The relatively small size of the sinkhole and lack of diagnostic evidence linking the SPR mine with it caused little concern initially. The location generally near the edge of the dome and near anomalous features in the salt stock suggested the possibility of an entirely natural origin (Neal, et al., 1993). A watch and wait position was adopted, and in March 1993 fluoroscein dye was placed in the sinkhole as a means of detecting connections with the underground mine, or to the surface downdip of the sinkhole. But by mid1993 it was apparent that the sinkhole was deepening, and there was monitoring data suggesting that the brine influx into the mine was increasing. Geomechanical calculations of long-term salt behavior showed that crack development would be predicted at peripheral positions over mined openings, thus providing a mechanism for eventual incursion of ground water.

Sinkholes also had formed under very similar conditions at other mines in domal salt (Neal, 1994). Thoms (1994) suggested that the salt under the sinkhole may have been geologically susceptible in addition to creating mining-induced stresses, as evidenced by several anomalous conditions that were noted during the original mining, including black salt, blowouts, and minor water leaks. Collectively the evidence suggested ongoing dissolution was increasing and that further study was required, in addition to engineering planning to address contingencies for decreasing risk of continued oil storage. 


\section{DIAGNOSTIC EFFORTS}

Unlike other mines where leaks can be observed underground, the SPR mine is sealed and must rely on indirect evidence such as increased pressure or changed isotopic composition of the contained water, which is about one percent of the total volume. Pressure diagnostics are complicated by salt creep closure, which is gradually reducing the storage volume by one-fifth of one percent per year $(\sim 160,000$ barrels), a very small amount overall, but a very large amount with respect to the few gallons per minute leaks which could explain the sinkhole.

Water inflow into the mine was suggested by increasing amounts of brine that was observable in the fill hole sumps, used for injecting oil during initial fill operations. While not a precise measurement, the inflow trend increased from one to nearly three gallons per minute in early 1994. This increase was noticed immediately following filling of the sinkhole with sand; the decision to fill was made because it had deepened to more than $12 \mathrm{~m} \mathrm{(40} \mathrm{ft)} \mathrm{and}$

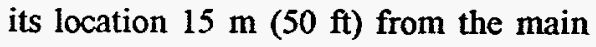
access road was hazardous. As soon as

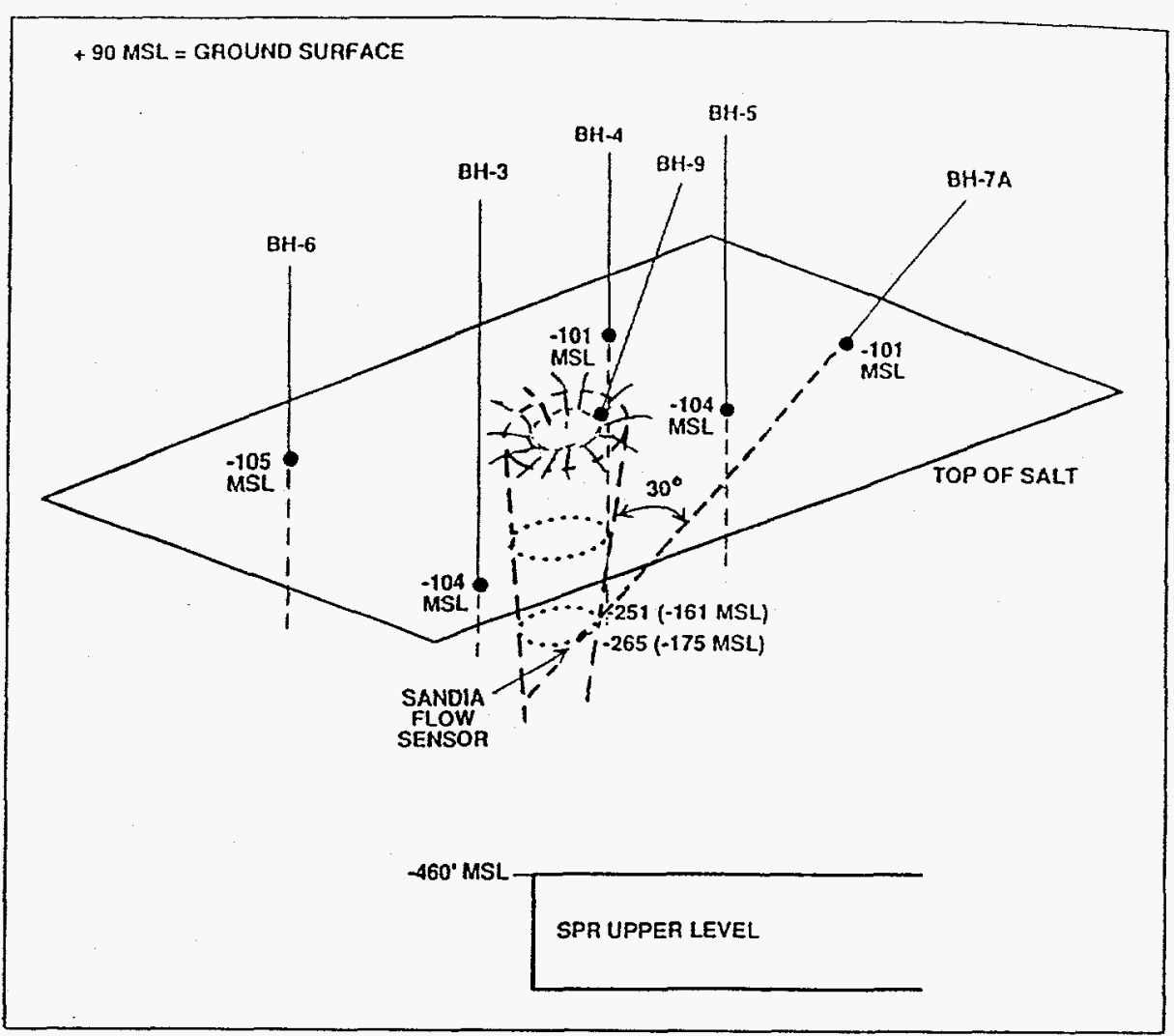

Figure 2 Location of boreholes BH-3, 4, 5, and 6 (drilled for crosswell tomography) and conceptual geometry of sinkhole relative to SPR oil storage. Angled exploratory holes BH-7A and 9 determined the throat geometry and enabled a hydrologic flowmeter to be placed 72 feet below the top of salt and into the sinkhole throat.

the fill was placed, continued settlement began occurring, at a rate of about $1.5 \mathrm{~m}^{3}$ a day, requiring new fill weekly. This suggested that dissolution was ongoing, and there appeared to be a rough correlation with the amount of increasing brine that was observed in the fill holes and the amount of unsaturated water required to leach an equivalent volume of salt.

Brine hydrochemistry is frequently analyzed in salt mines to distinguish meteoric water from connate water. At Weeks Island a decided change in isotopic composition was evident in comparing 1993 water from the fillhole sump with that obtained in late 1991, about the same time postulated for the sinkhole origin (Knauth, 1994). Although inconclusive, earlier data suggested that the leak may have existed as early as 1987.

Rock mechanics modeling by Ehgartner (1993) showed that the areas near the mine perimeter would be in tension and that fractures in salt could have formed as early as 1970 . Such a crack could be exposed to undersaturated ground water and gradually enlarge at the same time the crack was extending. The modeling results are validated by actual survey data showing subsidence over the mine, which is in close agreement with Ehgartner's modeling.

Seismic reflection profiling was conducted in the area of the sinkhole in early 1994, being an expedient technique to obtain subsurface information (Miller, et al., 1994). A prominent reflector first thought to be top-of-salt was noted throughout the area at shallow depth. Subsequent drilling, measurement, and geophysics showed that the reflector was essentially coincident with the piezometric surface, and that a localized $4 \mathrm{~m}(13 \mathrm{ft})$ deflection at the sinkhole was a possible drawdown created by the inflow of groundwater into the presumed point of leakage. A secondary anomalous step deflection was noted north of the main sinkhole, and caused some concern, realizing that sinkholes often progress and occur in multiples. Because sediment permeabilities are known to be very high, there is lack of agreement on the seismic reflector and it may not be the water table.

Crosswell seismic tomography was conducted by placing sources and receivers in diagonal cased boreholes on four sides of the sinkhole. The boreholes also provided direct information on sediment and salt geometry and the hydrologic environment. The steep deflection in the water table was observed on a neutron $\log$ in $\mathrm{BH} 44$, and measured directly on electrotape. The tomograms showed clear evidence of low-velocity material below the top of salt, verifying that a sediment-filled void occurred between the much higher velocity salt on either side. The graphical displays did not show the high quality imaging that some had anticipated, but the nature of the method is inherently limited to mapping seismic velocity distribution rather than geometry. However, the combination of 
drilling and tomography showed that the area of dissolution below the sinkhole is laterally limited, and with a strongly-vertical dimension.

Slanthole drilling directly into and below the sinkhole provided the most direct confirmation of dissolution geometry as evidenced by the drilling of boreholes BH-7A and BH-9 (Fig. 2) . Borehole \#9, adjacent to the sinkhole, was drilled at a high-angle approach directly over the top of the subsurface extension of the surface expression. It extended below the top-of-salt elevation encountered in the tomography holes. This wellbore provided the opportunity for injection of rhodamine dye into the apparent throat of the sinkhole. The dye, if detected in the fill holes, would provide unequivocal evidence of hydrologic connection with the mine; otherwise it is circumstantial. After several months of monioring, dye had not been detected in the mine.

Borehole \#7A started at a less steep angle and was aimed at the "plumbing" at depth. It penetrated the top-of-salt at the normal depth $(\sim 56 \mathrm{~m})$ and then continued on through salt into a major void at least $22 \mathrm{~m}(72 \mathrm{ft})$ deep. Fear of disnupting the channel stopped the drilling at this point, but not without first installing a 3-D hydrologic flowmeter which provided data for two weeks (SNL / DM, 1994). The data indicated essentially vertical flow down the throat, at a rate of $>1 \mathrm{~m}(3 \mathrm{ft}$ ) per day initially, and diminishing to $0.3 \mathrm{~m} /$ day. The $3 \mathrm{~cm}(\sim 1 \mathrm{in})$ per day downward movement of the flowmeter itself also indicated that sediment was moving down the throat, presumably in response to dissolution of salt by undersaturated groundwater at some point below. The discovery of this channel also provided the opportunity for additional injection of dye.

Near-surface gas mapping (hydrogen, methane, others) in the vicinity of the sinkhole was conducted, as this method has been employed in identifying leaking hydrocarbon sources elsewhere, as well as for oil exploration. The surveys did find localized areas of high hydrogen, but not in the sinkhole, High methane levels were found in the sinkhole, which alone without ethane would not confirm crude oil vapor (LSU, 1994). This study has not yet provided conclusive interpretations based on limited data but should not imply that the method was unsuccessful, as other anomalies were consistently measured.

Self Potential(SP) surveys were shown to be successful at other sinkhole occurrences by virtue of mapping streaming potential caused by groundwater flow; thus the method was tested at Weeks Island (SNL / DM, 1994). As anomalous drawdown was believed to occur near the sinkhole, it was thought that this method might reveal other indications, and possibly more about secondary areas of leakage, hinted at by apparent anomalous seismic reflections northeast of the main sinkhole. The data did show anomalies near the sinkhole, but also contained ambiguities. The anomalous streaming potentials were interpreted to probably result from vertical fluid flow along near-vertical planar surfaces. Perhaps just the indication of anomalous flow is sufficient, but further understanding of the sinkhole was not realized.

Piezometric monitoring and permeability testing was initiated in late 1994, as a means of observing the groundwater environment more directly. Permeability measurement was a high priority for determining grouting approaches, and for estimating other hydrologic conditions involving the water inflow. Permeabilities in the 4-12 darcy range and higher were measured in the alluvial sediments during several pump tests.

Progression of the sinkhole, including new occurrences, should be anticipated, based on similar experience elsewhere, and the continuing development of causative factors that produce the salt dissolution. In addition to monitoring subsidence annually over the entire mined areas, the surface has been visually observed for telltale changes. Because of the anticipated progression, several mitigative approaches were considered.

\section{MITIGATIVE EFFORTS}

Once the geometry of a deep void or crevasse was identified, with direct measurement of downward flow of water, the suggestion was made by Diamond and Mills (1994) to inject saturated brine directly into the throat through Borehole 7A. Beginning in August 1990 and continuing at present, approximately three gallons per minute is being gravity fed into the throat. The startling result was that subsidence at the sinkhole was arrested, and virtually no downward movement was measurable. In addition, the groundwater depression at the sinkhole had recovered to sea level. Evidently the brine had stopped the dissolution of salt, but whether this could be a longer-term fix was problematic. Plans for additional diagnostic drilling and grouting have continued, providing alternatives for the SPR operations.

Raising the internal mine pressure from $4.8 \times 10^{4}$ to $1.7 \times 10^{5} \mathrm{~Pa}$ ( 7 to $25 \mathrm{psi}$ ) was instituted in mid-1994 as a means of reducing inflow of brine. Although this increase was only a small amount, raising the pressure has the effect of reducing the external pressure gradient, as well as slowing salt creep closure (SNL / DM, 1994).

Grouting was considered early, but not yet instituted by late 1994 because of the lack of urgency, combined with the uncertainty about how and where to place grout, and the fear of doing more harm than good. Following completion of the diagnostics effort and mapping of the "plumbing," a decision will be made regarding the efficacy of permeation grouting. 


\title{
CONCLUSIONS
}

The sinkhole at Weeks Island formed over the edge of the mine as a result of geological, hydrological, and mine-induced factors. The location near the edge of the dome, astride a probable anomalous zone, set the stage for the mine configuration and boundaries. Mine geometry and excavation-induced stresses placed the mine periphery in tension, probably favoring crack development as early as 1970. Eventual incursion of undersaturated ground water traversed the $350 \mathrm{ft}$ salt back over the mine, allowing entry of brine into the SPR mine. Gradually increasing dissolution enlarged a void at the top of salt, creating the collapse environment for the sinkhole which formed circa 1990-91. Exploratory drilling and geophysics defined the void or crevasse beneath the sinkhole, enabling the introduction of saturated brine directly into the throat. The brine completely arrested the continuing subsidence at the sinkhole, apparently as a result of controlling ongoing dissolution. Additional drilling and piezometers will determine what additional mitigative steps are appropriate, e. g., grouting.

\section{REFERENCES}

Diamond, W. and K. E. Mills, 1994, Informal communication at a meeting of SPR participants and Morton Salt Company, July, 1994. The idea of injecting brine evidently was a collective, spontaneous decision arrived at by several individuals, most conspicuously Diamond and Mills.

Ehgartner, B. L., 1993, Weeks Island stress prediction and relationship to sinkhole formation. Sandia National Laboratories Department 6113 internal memorandum, 18 Oct. 1993, Albuquerque, NM.

Knauth, L. P., 1994, Stable isotope constraints on the origin of brine in the Weeks Island Strategic Petroleum Reserve. Arizona State University contract Report to DynMcDermott Petroleum Operations Company, New Orleans, LA,

LSU, 1994, Contract report from Institute for Environmental Studies, Louisiana State University to Sandia National Laboratories, Albuquerque, NM, 29 July, and October 1994.

Miller, R. D. et al. , 1994, High resolution seismic survey near SPR surface collapse feature at Weeks Island, Louisiana, Contract report, Kansas Geological Survey to Sandia National Laboratories, Albuquerque, NM.

Neal, J. T. et al., 1993, Anomalous Zones in Gulf Coast salt domes, with special reference to Big Hill, Texas, and Weeks Island, Louisiana. Albuquerque, NM, Sandia National Laboratories Report SAND92-2283, 65 p.

Neal, J. T., 1994, Surface features indicative of subsurface evaporite dissolution: implications for storage and mining. Solution Mining Research Institute Spring Meeting, Houston, TX, 25-27 Apr. 94.

SNL / DM, 1994, Update of assessment of geotechnical risks; Strategic Petroleum Reserve, Weeks Island Site. Sandia National Laboratories, Albuquerque, NM, and DynMcDermott Petroleum Operations Company, New Orleans, LA. In press.

Thoms, R. L., 1994, Weeks Island Sinkhole. Draft report submitted to Sandia National Laboratories, Department 6113 internal con tract with AGM Inc., Feb. 1994.

\section{DISCLAIMER}

\begin{abstract}
This report was prepared as an account of work sponsored by an agency of the United States Government. Neither the United States Government nor any agency thereof, nor any of their employees, makes any warranty, express or implied, or assumes any legal liability or responsibility for the accuracy, completeness, or usefulness of any information, apparatus, product, or process disclosed, or represents that its use would not infringe privately owned rights. Reference herein to any specific commercial product, process, or service by trade name, trademark, manufacturer, or otherwise does not necessarily constitute or imply its endorsement, recommendation, or favoring by the United States Government or any agency thereof. The views and opinions of authors expressed herein do not necessarily state or reflect those of the United States Government or any agency thereof.
\end{abstract}

